\title{
DISGORGEMENT DAMAGES FOR BREACH OF CONTRACT
}

\author{
Adam Temple*
}

Gain-based damages for breach of contract are often viewed as anomalous, and lacking a clear rational basis. This article seeks to provide a theoretical basis for the requirement to disgorge profits gained through breach of contract. By looking at the core contractual obligation, it can be seen that a contracting party has two ways in which they can fulfil their promises. They can pay damages where they fully compensate the other party, or they can perform. Where damages are inadequate, the contracting party must perform. Failure to perform in such circumstances should be prevented, and it is argued that disgorgement of profits is a suitable deterrent to such contract breakers. It is suggested that the law should act in this way to protect the facilitative institution of contract.

\section{INTRODUCTION}

Not so long ago it would not have been contentious to suggest that gainbased damages have secured a foothold in the law of contract. Following Attorney General v Blake, ${ }^{1}$ it seemed that there was plenty of scope for argument about when gain-based damages were appropriate, but little room for suggesting that they should never be available. Following the Court of Appeal's decision in the $W W F$ case, ${ }^{2}$ and Lord Scott's speech to the Chancery Bar Association, ${ }^{3}$ it appears that the tide of opinion may be again turning against such damages. The thrust behind both of those criticisms was that the award in Blake is best interpreted as compensatory in nature; the defendant's profits providing the measure of a loss that was difficult to measure.

This article considers the various arguments that have aligned for and against the introduction of gain-based damages, and focuses on the area that

\footnotetext{
* BA, BCL (Oxon). I would like to thank William Swadling of Brasenose College, Oxford, who supervised the original version of this article. All errors remain my own. Thanks are also due to Jeffrey Hackney and Laura Hoyano of Wadham College, who guided my first, faltering, steps into the world of law.

${ }_{1}^{1}$ Attorney General v Blake (Jonathon Cape Ltd Third Party) [2001] 1 AC 268.

2 WWF-World Wide Fund for Nature (formerly World Wildlife Fund) $v$ World Wrestling Federation Inc [2007] EWCA Civ 286.

${ }^{3}$ Published, with slight revisions, as Lord Scott "Damages" [2007] LMCLQ 465.
} 


\section{DISGORGEMENT DAMAGES FOR BREACH OF CONTRACT}

appears to trouble commentators on both sides of the divide: whether and when contract breaches should be deterred. This question is then examined from first principles, asking why contracts are ever enforceable. The way in which one defines the basic contractual obligation is then used to inform the discourse on deterrence. It is argued that this analysis identifies some breaches of contract that require deterrence, wherever the breach leaves the losing party without any of the benefit contracted for.

\section{TERMINOLOGY}

When considering the question whether a contract-breaker who thereby profits ought to give up that profit, it should be remembered that a number of different terms have been used to describe such an award. Sums awarded have variously been described as "an account of profits", "restitutionary damages", 5 and "disgorgement damages." "Those who use the "disgorgement" tag tend to do so to differentiate between those awards which are based upon the movement of some value between claimant and defendant, which has to be given back (a restitutionary award), as opposed to gains made by the defendant from another source which the claimant wants to be given up (a disgorgement award). As the situation with which this article is concerned relates to the "giving up" of profit, I accordingly use the "disgorgement" tag. It has the additional benefits of perspicacity of meaning; it clearly differentiates between this area and that of unjust enrichment, where the term "restitutionary" is standard, and it better reflects the idea of "giving up" the profit.

\section{ARGUMENTS IN FAVOUR OF DISGORGEMENT DAMAGES}

In this section I consider the arguments that have been put forward in favour of the availability of disgorgement damages.

\section{(a) "A Wrongdoer Shall Not Be Allowed to Profit from Her Own Wrong"}

The most basic reason given for requiring disgorgement of profits is that the defendant ought not to be able to commit a wrong and retain the benefits gained therefrom. Thus, in considering the Blake case, Lord Nicholls said that

\footnotetext{
${ }^{4}$ Used by Lord Nicholls in Blake, above $\mathrm{n} 1$.

5 PBH Birks An Introduction to the Law of Restitution (Oxford: Clarendon Press, 1985); AS Burrows The Law of Restitution (London: Butterworths, 2nd edn, 2002).

${ }^{6}$ J Edelman Gain-Based Damages: Contract, Tort, Equity and Intellectual Property (Oxford: Hart, 2002); P Jaffey "Restitutionary Damages and Disgorgement" [2001] RLR 578.
} 
"[t]he broad proposition that a wrongdoer should not be allowed to profit from his wrong has an obvious attraction."7 As a reason for making disgorgement damages available, this statement lacks any firm grounding; it is nothing more than an assertion of a vague moral position. It completely fails to tell us what "wrongs" are to be included within the principle, and why the claimant should be the proper recipient of the defendant's gain. Indeed, most authors accept that this proposition is over-broad, so limit their contention to the more limited idea that profits ought not to be retained in certain situations.

\section{(b) The Cynical Defendant}

Edelman regards deterrence as the reason why disgorgement damages ought to be available for breach of contract. One type of breach which needs to be deterred, in his view, is where the defendant has acted "deliberately and cynically." 8 Disgorgement damages are required, according to this rationale, because the compensatory measure allows the wrongdoer to calculate the extent of such damages in advance, so as to calculate whether she can make a greater profit than she would have to pay out. Any person who is willing to breach their duty to somebody else in order to make a profit for themselves is thus caught by the test. In Edelman's view, then, all deliberate breaches of contract ought to give the claimant the choice whether to seek disgorgement of the defendant's profits instead of compensation for her loss; all such breaches need to be deterred.

The "cynical contract-breaker" test is also the one adopted by Birks ${ }^{9}$ in his article advocating the possibility of stripping such defendants of their profits. Despite the apparently broad question that he asks at the start of the article, ${ }^{10}$ however, Birks adds an important restraint on the availability of disgorgement damages (he calls them "restitutionary damages"), in that:

"There should be no recourse to restitutionary damages - not even in the case of cynical breach for the sake of gain - unless on the particular facts compensatory damages are demonstrably an inadequate remedy..."

\footnotetext{
${ }^{7}$ Blake, above n 1, p 278.

${ }^{8}$ Edelman, above n 6, p 84.

${ }^{9}$ PBH Birks "Restitutionary damages for breach of contract: Snepp and the fusion of law and equity" [1987] LMCLQ 330.

${ }^{10}$ Birks asks, ibid, at 330: "Suppose someone sees that by breaking his contract he can make a substantial profit: then, calculating that his likely gains will far outweigh any loss for which he might have to compensate his victim, he cynically decides to throw his contract over. In that strong case ... can the victim claim the contract breaker's profits?"

${ }^{11}$ Ibid, at 342.
} 


\section{DISGORGEMENT DAMAGES FOR BREACH OF CONTRACT}

Birks thus limits the category of cases in which disgorgement damages ought to be available to those where compensation fails to adequately protect the claimant. He regards the move towards allowing disgorgement damages for breach of contract as necessary to avoid the abuse of other legal concepts which have been used to reach the same result. He points to two cases, British Motor Trade Association $v$ Gilbert $^{12}$ and Reid-Newfoundland Telegraph $v$ Anglo-American Telegraph $\mathrm{Co}^{13}$ as demonstrating these "legal contortions" where the courts have given disgorgement damages, whilst denying that they are departing from the compensatory measure of damages.

\section{(c) Institutional Protection}

Another argument that can be advanced for allowing disgorgement damages is that deterrence is required in order to protect the facilitative institution of contract. The idea that legal institutions require protection by deterring wrongs that harm those institutions was put forward by Jackman, ${ }^{14}$ and the theory is most clearly borne out by the availability of disgorgement damages for breach of fiduciary duty, as exemplified by Boardman $v$ Phipps. ${ }^{15}$ The argument suggests that a legal institution may be undermined by conduct, even if it does not cause the individual claimant any harm. So, fiduciary relationships require that the fiduciary act solely for the benefit of the other party, and the fiduciary is not permitted to make a profit for herself. In Boardman $v$ Phipps the solicitor acted on information gained in his role as fiduciary and, even though his actions were profitable for the beneficiary of the duty, he was obliged to disgorge his profits in order to maintain the institution of fiduciary relationships.

Jackman is ambivalent as to whether the institutional protection argument ought to extend to breaches of contract. On the one hand he concedes that compensatory damages which put the claimant in the position she would have been in had the contract been performed can be seen to provide "sufficient institutional protection to maintain that degree of stability which is essential to any practice of promise-making." ${ }^{16}$ On the other hand he considers that a deliberate profitable breach might provide sufficient moral opprobrium to require disgorgement damages, in order to protect the institution. Jackman's tentative suggestion that the institution of contract could require protection in some circumstances appears similar to that of Birks; whilst he considers that

\footnotetext{
12 [1951] 2 All ER 641.

13 [1912] AC 555.

14 I M Jackman "Restitution for Wrongs" [1989] CLJ 302.

${ }^{15}$ [1967] 2 AC 46.

${ }^{16}$ Jackman, above n 14, at 320.
} 
compensation will normally be an adequate response, he recognises that in some situations harm to the institution will result if only that measure is applied, and so deterrence might be appropriate.

\title{
(d) Personal rights require the same protection as property rights.
}

Another argument exists, presented by Friedmann ${ }^{17}$ and Smith $^{18}$ and supported by the Supreme Court of Israel, ${ }^{19}$ that contractual rights are to be seen as the equivalent of property rights, and that when one breaches one's contract one is depriving the other party of a right in a similar way as if one had taken their bicycle. The essence of Smith's argument is that:

"If disgorgement is not allowed and the wrongdoing defendant is allowed to keep the gain, then in essence the court is allowing rights to be expropriated." 20

He regards this as being true in relation to both personal rights, including breach of contract, and property rights. It is essential, in Smith's view, that both groups of right are treated in the same way because he considers there to be very little difference between them. He admits that personal rights are only rights against particular individuals, whilst proprietary rights are rights against an indefinite class of people, but regards this as the only difference. As such he denies that there are any relevant differences in the content of the rights.

Friedmann's arguments are similar to those of Smith, arguing that denial of performance amounts to the deprivation of an interest that "belonged" to that contractual party. His argument, however, is slightly different, in that he places less emphasis on the idea of expropriation of rights, but instead focuses on the extent of protection that they deserve. He claims that:

\begin{abstract}
"Limitation of a [claimant's] remedy to damages tends to trivialize the importance of contractual obligations, undermining faith in their seriousness and confidence in each party's ability to rely on full performance." 21
\end{abstract}

${ }^{17}$ D Friedmann "Restitution of Benefits Obtained Through the Appropriation of Property or the Commission of a Wrong" (1980) 80 Colum L Rev 504.

${ }^{18}$ LD Smith "Disgorgement of the Profits of Breach of Contract: Property, Contract and "Efficient Breach"' (1995) 24 Canadian Business LJ 121.

${ }_{19}$ Adras Building Material Ltd v Harlow \& Jones Gmbh [1995] Restitution Law Review 235.

${ }^{20}$ Smith, above n 18 , at 122-123.

${ }^{21}$ Friedmann, above n 17, at 515. 


\section{DISGORGEMENT DAMAGES FOR BREACH OF CONTRACT}

These arguments tend to place less emphasis on the deterrence of particular types of breaches of contract, and seek to deter all breaches, as they undermine the integrity of personal rights.

\section{ARGUMENTS AGAINST THE AVAILABILITY OF DISGORGEMENT DAMAGES}

Arguments against the availability of disgorgement damages appear to implicitly assume that breaches of contract need not be deterred. Compensatory damages, under these theories, are sufficient protection for contractual obligations.

\section{(a) Corrective Justice}

Weinrib centres his theory around the notion of corrective justice so that, for him, "[t]he parties do and suffer injustice only with respect to ... loss." 22 Where such losses arise compensatory damages address the loss, and thus address the injustice. There is nothing else with which the law should be concerned. Damages which focus upon the gain made by the defendant, as disgorgement damages do, fail to live up to Weinrib's requirement of correlativity, in which the question of injustice is answered by focusing on the relationship between the parties. There is no sufficient link, in his view, between the particular claimant and the profit, which requires that it be paid over; for him the claimant has no interest in whether the defendant makes a gain, all that should concern the defendant is the correction of her loss. Weinrib says that:

"The remedy consists of the restoration by the defendant (so far as the law can achieve it) of what rightly belongs to the [claimant], thereby undoing the injustice suffered by the [claimant]." ${ }^{, 23}$

The thing that "rightly belongs" to the claimant, in Weinrib's argument, is the "performance to which the claimant was entitled." ${ }^{24}$ The restoration is effected by the payment of damages based on the performance interest. Provided that corrective justice is thus satisfied, there appears to be no room in Weinrib's theory for notions of deterrence. Deterrence, as far as it concerns itself more generally with protecting personal rights, preventing cynical

${ }^{22}$ EJ Weinrib "Restitutionary Damages as Corrective Justice" (2000) 1 Theoretical Inquiries in Law 1, at 11.

${ }^{23}$ EJ Weinrib "Punishment and Disgorgement as Contract Remedies" (2003) 78 Chicago-Kent L Rev 55, at 61.

${ }^{24}$ Ibid, at 68 . 
breaches or protecting the law's facilitative institution, is external to the relationship between the parties. Such external factors are anathema to Weinrib, who claims that the law should be entirely intelligible from within the context of the bilateral relationship between claimant and defendant. He does not deny that some deterrence may be desirable, but says that any action against these harmful breaches "must be located within criminal rather than private law." 25

Weinrib's position has been echoed in a speech by Lord Scott. ${ }^{26}$ His Lordship suggested that general deterrence has no place in private actions, and questions the use of civil courts to "pursue the protection of the rights of the public at large" 27 or to punish defendants.

\section{(b) The Theory of Efficient Breach}

The arguments in favour of disgorgement damages discussed above are, in the eyes of some, directed at a problem that does not exist, in that they are aimed at preventing breaches of contract. For those who believe in the paramount importance of economic efficiency, ${ }^{28}$ there is no need to deter breaches of contract. They consider it beneficial for a party to leave a contract where she has a more profitable option elsewhere, bearing in mind that she will have to pay compensation to the other party. After all, the award of compensation to the claimant ought to place that party in the position she would have been in had the contract been performed, so she should have no complaint. If the defendant can make extra profit then everybody appears to be better off. A "cynical" breach, which Edelman sees as requiring deterrence, would not be a problem under such a scheme, indeed it is to be encouraged. ${ }^{29}$ This theory requires a system of compensation that covers all losses to the claimant, as is made clear by Campbell and Harris:

"If the damages system works in the sense that damages actually are adequate, the claimant should be indifferent whether the defendant pays damages or performs." 30

\footnotetext{
${ }^{25}$ Ibid, at 86 .

${ }^{26}$ Above, n 3 .

${ }^{27}$ Ibid, at 472 .

${ }^{28}$ R A Posner Economic Analysis of Law (New York: Aspen, 6th edn, 2003) p 119.

${ }^{29}$ Posner (ibid) does include one exception, where "a promisor breaks his promise merely to take advantage of the vulnerability of the promisee ... we may as well throw the book at the promisor." Such breaches are regarded as inefficient, and thus can be deterred. This does not undermine Posner's major point that breaches, for whatever motive, should not be deterred if they are economically efficient.

${ }^{30}$ D Campbell and D Harris "In Defence of Breach: a Critique of Restitution and the Performance Interest” (2002) 22 Legal Studies 208 at 219.
} 


\section{DISGORGEMENT DAMAGES FOR BREACH OF CONTRACT}

They recognize, however, that compensation is not always adequate, especially where there are "idiosyncratic" losses depending upon the situation of the contracting parties. In such cases Campbell and Harris place a great deal of emphasis upon the ability of parties to tailor their agreement to provide the degree of protection that they consider themselves to need. As such, the default rules of contractual damages ought to depend upon what most commercial parties could be expected to want, to save transaction costs of contracting out of such background rules. They regard disgorgement damages as out of line with what commercial parties want, and a move to a position whereby performance is enforced, which is contrary to the flexibility that the current system engenders.

The theory of efficient breach does not consider that there is any need to deter breaches. Indeed, breaches are defended as necessary to ensure economic efficiency.

\section{WHEN DO WE NEED TO DETER BREACH OF CONTRACT?}

The arguments above, for and against disgorgement damages, have fundamentally different conceptions of whether breaches of contract should ever be deterred. Those in favour of making disgorgement damages available appear to do so because they wish particular kinds of breach to be deterred. For those that argue against the availability of disgorgement damages, on the other hand, the idea of deterrence is anathema. This section is aimed at asking whether we should ever want to deter breach of contract and, if so, what marks out those breaches that need to be deterred.

In order effectively to answer this question it is important to go back to the more basic question of what a contract entitles the contracting party to receive. Some authors have tried to deny that the choice of secondary obligations $^{31}$ in contract is necessarily connected with the underlying obligation. ${ }^{32}$ Birks has argued, when discussing civil wrongs in general, that

${ }^{31}$ The term "secondary obligations" derives from Lord Diplock's speech in Photo Production v Securicor Ltd [1980] AC 827, where the term was used to refer to those obligations that arise from a breach of contract. I am using the term in a slightly broader sense, to include any court order that can be obtained upon a breach or threatened breach.

${ }^{32}$ R Craswell "Contract Law, Default Rules, and the Philosophy of Promising", (1989) 88 Michigan LR 489 does this explicitly, whilst Fuller and Purdue "The Reliance Interest in Contract Damages" (1936) 46 Yale LJ 373 do so implicitly, recognising the will theory as the basis of contract, but failing to see any relevance in this when it comes to remedies. 
"civil wrongs ... dictate no particular response", ${ }^{33}$ but there is much force in Friedmann's argument that "the very recognition of a legal right entails some consequences regarding the remedy." " Where a number of legal responses are possible, it would appear logical that the law should choose those responses that most accurately reflect the underlying obligation that has been broken. The remedies given upon the breach of a contractual right should reflect the content of the underlying contractual right.

In English law, at least, it is irrefutable that upon the valid formation of a contract each party is bound by his promise contained therein. The promise is to perform; as Roskill LJ has said "[i]n principle contracts are made to be performed." ${ }^{35}$ It is not true, however, that the law always treats the promise as creating an obligation to perform, and nothing else. The promise does bind the promisor, but the law only demands adherence to that promise to the extent of not disappointing the promisee's expectations that are generated thereby. In the words of Fried:

"Put simply, I am bound to do what I promised you I would do - or I am bound to put you in as good a position as if I had done so."

This approach is similar to the oft-quoted statement from Oliver Wendell Holmes, that " $[t]$ he duty to keep a contract at common law means a prediction that you must pay damages if you do not keep it - and nothing else." ${ }^{37}$

It would be possible for the law to focus on performance, as it does in other legal systems. In such systems specific performance remedies are paramount, and all breaches are discouraged. This can be seen in the approach taken by the Supreme Court of Israel, which has held that the disgorgement of gains is a useful deterrent against breach, saying that it was important to shift the emphasis "from the loss resulting from breach to the breach itself." 38 This reflects the general rule in Israeli law that a party to a contract is entitled to specific performance, meaning that deterrence of all non-performance is needed.

${ }^{33}$ P B H Birks "The Concept of a Civil Wrong" in D Owen (ed) Philosophical Foundations of Tort Law (Oxford: Clarendon Press, 1995) p 34.

${ }^{34}$ D Friedmann "The Performance Interest in Contract Damages" (1995) 111 Law Quarterly Review 628 at 637.

${ }^{35}$ Cehave NV v Bremer Handelsgesellschaft GmbH (The Hansa Nord) [1976] 1 QB $44, \mathrm{p} 71$.

${ }^{36}$ C Fried Contract as Promise (Cambridge, Massachusetts: Harvard University Press, 1981).

${ }^{37}$ OW Holmes "The Path of the Law" (1897) 10 Harvard L Rev 457 at 462.

${ }^{38}$ Adras, above n 19, S Levin J, p 241. 


\section{DISGORGEMENT DAMAGES FOR BREACH OF CONTRACT}

A legal system makes a choice, and that choice entails consequences for individual contractual promises. This is analogous with Fried's explanation as to why promises themselves have binding effect:

"To have force in a particular case promises must be assumed to have force generally. Once that general assumption is made, the effects we intentionally produce by a particular promise may be morally attributed to us." 39

So, once a system decides upon either the duty to "perform or pay" or the duty to "perform at all costs", that duty will attach to any given contractual promise.

English law follows Fried in accepting that the payment of a sum to put the other party in the position she would have been in, had the contract been performed, is sufficient to remedy the breach of contract. The proof for this lies in the acknowledged primacy of the expectation measure of damages: "the general principle regarding assessment of damages is that they are compensatory for loss or injury." "The House of Lords in Blake focused on compensation, before moving on to consider situations where the general principle is not applied.

The "perform or pay" principle, above, was illustrated by quotations from Fried and Holmes. They are not the same. Fried stated that the obligation is to perform or to place the other party in the position she would have been in had the contract been performed. Holmes, however, said that the obligation to perform only extended to the requirement to pay damages if in breach; "[i]f you commit a contract, you are liable to pay a compensatory sum unless the promised event comes to pass." ${ }^{\prime 41}$ Fried's formulation shows that the law accepts that the performance interest has two ways of being fulfilled; the promisor may perform, or she may pay damages to put the other person in the same position as if she had performed. The ability to satisfy the law in the latter sense rests on the idea that the payment of damages would be a sufficient substitute for actual performance. It follows, therefore, that if the payment of damages would not put the other party in the position as if the contract had been performed, then the performance interest can only be fulfilled by actual performance. This is different from Holmes' formulation, who casts the principle in terms of a free choice. The choice, for Fried, is restricted by the requirement that damages must be an adequate substitute for performance; if they are not, then the choice does not exist. Fried's

\footnotetext{
${ }^{39}$ Fried, above $\mathrm{n} 36$, at 12.

${ }^{40}$ Lord Nicholls in Blake, above n 1, at 278.

${ }^{41}$ Holmes, above $\mathrm{n} 37$, at 462 . The phraseology of 'committing a contract' is odd; it is used by Holmes as a contrast to the idea of committing a tort.
} 
formulation does appear to reflect the position in English law. This is demonstrated by the availability of the remedies of injunctions and specific performance in those cases where the performance interest would be insufficiently protected by an award of monetary damages. Such cases usually arise when the performance at issue could not be obtained elsewhere on the open market, such as the sale of a particular piece of land. It is submitted that this is a recognition of the inadequacy of damages in such cases, and the need for the law to provide alternative secondary obligations to oblige the promisor to fulfil their promise.

This leads us to the conclusion that non-performance of a contract does not always need to be deterred. The performance interest is only left unfulfilled in those few cases where monetary damages are not an adequate substitute for the claimant's primary rights, and where specific performance is not possible. It is only in such situations that we would want deterrence, because the contract breaker is failing to live up to their core contractual obligations, as described above.

It is the availability of specific performance and injunctions that tells us when the normal award of compensatory damages is insufficient to protect the performance interest. It is important to note, however, that deterrence after non-performance does not perform the same role as damages or specific performance. Those awards are given in order to ensure fulfilment of the core contractual obligation. It is the impossibility of living up to the performance interest, on the other hand, which gives us our reason for wanting to deter. The idea of deterrence is therefore to prevent such wrongful nonperformances occurring in future, whereas specific performance is used to ensure actual performance in the case at hand.

It can be asked how this result, on the question of which breaches of contract need deterring, differs from the arguments concerning the availability of disgorgement damages considered above. It is broadly in line with Jackman's concerns for the protection of facilitative institutions, but does not bite in all situations where the defendant makes a profit. Instead, disgorgement damages should only be available where the standard secondary obligations leave the institution insufficiently protected.

On the other side of the equation, Campbell and Harris's argument in defence of breach and the expectation interest relies on the generally applicable secondary obligations leaving the claimant "indifferent" to the fact of breach. Damages, or the possibility of specific performance, do sometimes leave the claimant with a genuine grievance in those situations where they leave her performance interest unfulfilled, and therefore she would not be "indifferent" to the breach. Where the claimant is left with such a grievance, it is submitted that deterrence is needed and that the economic efficiency arguments lose their force. 


\section{DISGORGEMENT DAMAGES FOR BREACH OF CONTRACT}

Those who wish to deter all breaches, or that don't think any breaches need deterring, do not fit in with the line taken here. It has been argued that they fail to take into account the approach towards the performance interest taken by English law, reflected by the secondary obligations that are imposed upon breach.

In particular, the argument that personal rights should be treated in a similar way to property rights is not in line with English law. They posit a merely quantitative difference between personal rights and property rights, in terms of the number of people against whom they are exigible. ${ }^{42}$ The difference is more important than this, the difference between personal rights and property rights being that "the former goes to an object, the latter to an action." ${ }^{43}$ In other words, the difference between property rights and personal rights is not merely quantitative, it is qualitative. It can be seen that whilst the expropriation of property rights is conceptually simple, the idea of expropriating personal rights makes no sense. If I contract with you to paint your house, and fail to do so, I have broken my promise to you, but I cannot be said to have taken your right, to have your house painted, for myself.

The question of the cynicism of the defendant has not yet been addressed. It is clear from the above analysis that this test cannot form the basis of the availability of disgorgement damages, which is related to deterrence in order to protect the institution of contract law. The motive for breach could, however, enter into the picture as a limiting factor, so that innocent contractbreakers are not bound to disgorge their profits. This proposition must be rejected. The idea that the mental element should additionally have to be proved adds complication to the law, and could undermine the goal of deterrence. The law should be aimed at preventing claimants' performance interests from being left unfulfilled, and the defendant's mental state does not affect that issue. Deterrence is focused on deterring future similar breaches, and the motive of the defendant in the particular case is therefore irrelevant. The same approach is taken in cases where fiduciaries are made to account for their profits, despite their innocence; ${ }^{44}$ the law acts to deter similar breaches in future, which would undermine the law's institutions.

The analysis above has been aimed at fleshing out the conception that deterrence is only needed where damages are insufficient. This is idea is used by Birks, ${ }^{45}$ and is reflected in the Blake judgement, considered below, but is often stated as a limiting factor on disgorgement damages without any reasons for setting the limit at that point. Instead of viewing the requirement of the

${ }^{42}$ E J Weinrib "Punishment and Disgorgement as Contract Remedies" (2003) 78 Chicago-Kent L Rev 55.

${ }^{43}$ Ibid, at 81 .

${ }^{44}$ Keech v Sandford (1726) All ER Rep 230; Boardman v Phipps [1967] 2 AC 46.

${ }^{45}$ Above $\mathrm{n} 5$. 
insufficiency of compensation as a limiting factor on disgorgement damages, it has been argued that the insufficiency in fact provides a basis for disgorgement damages.

\section{DISGORGEMENT DAMAGES AS DETERRENT}

The requirement to pay disgorgement damages has a deterrent effect that is precisely equal to the incentives that the contract-breaker had for breaking her promise. Any contractor, who acknowledges in advance that their breach of contract is going to undermine the promisee's performance interest, ought to recognise that there is no good reason to breach.

The case of Lake $v$ Bayliss ${ }^{46}$ involved a contract for the sale of land but, prior to conveyance, the vendor sold the land again to a third party, for a profit. The case was decided on trust principles, but it is submitted that this is precisely the kind of case where the breach of a contract does need to be deterred, even if the defendant were willing to pay damages. The law recognises the uniqueness of contracts for the sale of land, and would usually provide for specific performance; damages are recognised not to be a fully adequate substitute. Therefore, by selling the land a second time the vendor prevented the original purchaser from receiving performance. The availability of disgorgement damages should make a landowner, considering whether to sell their land twice, see that there is no advantage to be gained by such action.

Admittedly, the equivalence of deterrence to incentive does not provide reasons why punitive damages ought not be used. It could be expected that when faced with the possibility of even greater damages the chances of wrongful breaches would be reduced. Disgorgement damages could thus be seen as an insufficient deterrent; Lord Diplock, when referring to the legitimacy of punitive damages in tort law, pursues this argument:

"It is only if there is a prospect that the damages may exceed the defendant's gain that the social purpose ... is achieved - to teach a wrong-doer that tort does not pay.,"47

There are a number of problems with a proposal to extend punitive damages to the law of contract. Firstly, there is much controversy about the existence of punitive damages in the law as it stands, which does not make such awards available for breach of contract, ${ }^{48}$ and so the idea of extending

\footnotetext{
${ }^{46}$ [1974] 1 WLR 1073.

${ }^{47}$ Broome v Cassell \& Co [1972] AC 1027 at 1130.

${ }^{48}$ Although a profitable breach of contract could appear to fall within Lord Devlin's second category in Rookes v Barnard [1964] AC 1129 where "exemplary" damages
} 


\section{DISGORGEMENT DAMAGES FOR BREACH OF CONTRACT}

their availability is problematic. It is notable that the Law Commission, whilst advocating the extension of punitive damages, specifically limits such extension to "any tort or equitable wrong" 49 and excludes breach of contract, ${ }^{50}$ whilst leaving to the courts the possibility of disgorgement damages for breach of contract. ${ }^{51}$

A second argument against using punitive damages is the fact that, as considered above, the availability of disgorgement damages is closely attuned to the incentive which the defendant had to breach in the first place. To strip her of those profits is therefore necessary in order for the damages to have a deterrent function. A measure of damages that goes further than that, however, is disproportionate in requiring the defendant to pay more than is necessary to secure deterrence.

\section{WHY GIVE A “WINDFALL” TO THE CLAIMANT?}

The argument that deterrence is needed in a particular case focuses on the proposition that in such cases compensatory damages are insufficient to represent the lost performance. This would normally mean that specific performance would be granted, but where that is not possible then the breach must be deterred. However, the recognition that disgorgement damages could act as a deterrent against such breaches means that the size of the monetary award to the claimant appears to lose all anchorage to the size of loss.

It is understandable that some might strive to prove the presence of loss in all circumstances, as our understanding of what it is to be a "victim" requires harm. In addition, most would accept the warnings of Mill, that "the only purpose for which power can be rightfully exercised over any member of a civilised community, against his will, is to prevent harm to others." ${ }^{\text {"5 }}$ This concern is reflected in the statement by Glidewell LJ in Halifax Building Society $v$ Thomas, where he said:

may be awarded (where the "defendant's conduct has been calculated by him to make a profit for himself which may well exceed the compensation payable to the plaintiff') Lord Devlin only refers to teaching "a wrongdoer that tort does not pay". All invocations of the second category restrict it to tort claims, as in the quotation from Lord Diplock, above. In ABv South West Water [1993] QB 507 the test was explicitly said not to apply to breaches of contract, though the case was later overruled (not on this point) in Kuddus v Chief Constable of Leicestershire [2002] 2 AC 122.

${ }^{49}$ Law Commission of England and Wales Aggravated, Exemplary and Restitutionary Damages (Law Com No 247, 1997) para 5.44.

${ }^{50}$ Ibid, para 5.71 .

${ }^{51}$ Ibid, para 3.47.

52 J S Mill Utilitarianism, Liberty, Representative Government (London: Everyman Editions, 1910). 
"The proposition that a wrongdoer should not be allowed to profit from his wrongs has an obvious attraction. The further proposition, that the victim or intended victim of the wrongdoing, who has in the event suffered no loss, is entitled to retain or recover the amount of the profit is less obviously persuasive." ${ }^{53}$

Even conceding that the claimant could receive more than any conceivable value of the lost performance, the payment of disgorgement damages may still be explained on the basis that "overcompensating the claimant is a lesser evil than leaving the defendant with ill-gotten gains." 54 Another way of defending the claimant's receipt is that we need to give the claimant an incentive to bring these cases to court, in order that the defendant may be stripped of her profit, so that future cases may be deterred. If the claimant could only receive money for provable losses then there may be no point in suing the contract-breaker. As McInnes has noted "the prospect of a windfall gain motivates him to sue." 55

Persuading the Claimant to sue is important if we take deterrence of future actions seriously. It is conceded that the value of disgorgement damages is not in any way tied to the claimant's loss, but appeals to the greater need to protect the institution of contract, and those future contractors who would otherwise be left with no performance.

That the law acts through private litigation in order to protect its facilitative institutions in other contexts is demonstrated by the cases of Keech $v$ Sandford ${ }^{56}$ and Boardman $v$ Phipps. ${ }^{57}$ A fiduciary can be made to account for all profits, in order to protect the equitable institution, even if no opprobrium is attached to the fiduciary's actions. As was said in 1726:

"It may seem hard that the trustee is the only person of all mankind who might not have the lease, but it is very proper that rules should be strictly pursued, and not in the least relaxed; for it is very obvious what would be the consequence of letting trustees have the lease on refusal to renew to cestui que use." 58

This example undermines the arguments of those that suggest that private law should have no interest in issues that are external to the two parties in litigation. There are many other examples where the courts covertly take

\footnotetext{
${ }^{53}$ [1996] Ch 217, p 229.

${ }^{54}$ A S Burrows The Law of Restitution (London: Butterworths, 2nd edn, 2002) p 480.

${ }^{55}$ M McInnes "Interceptive Subtraction, Unjust Enrichment and Wrongs-A Reply to Professor Birks" [2003] Cambridge Law Journal 697 at 706.

${ }^{56}$ (1726) All ER Rep 230.

${ }^{57}$ [1967] 2 AC 46.

58 Above n 56.
} 


\section{DISGORGEMENT DAMAGES FOR BREACH OF CONTRACT}

broader social considerations into account, but the defence of fiduciary duties is one area where the law is happy to acknowledge the influence of questions such as deterrence.

\section{WHERE DOES ENGLISH LAW STAND?}

Having established a basis upon which the availability of disgorgement damages can be justified, it is necessary to see whether this approach is consistent with the case-law.

\section{(a) The Law Prior to Blake}

It is possible to find many statements in the cases prior to Blake to the effect that the purpose of damages is only to compensate for loss. ${ }^{59}$ However, as Birks has pointed out, there are a number of cases where the defendant's gain formed the basis for the calculation of the damages payable. He identifies such cases as awarding disgorgement damages (which he calls "restitutionary"), but disguising them as compensatory only through "intellectual contortions." 60

The first case is Reid-Newfoundland Co v Anglo-American Telegraph $C o,{ }^{61}$ where the appellants, telegraph wire operators, took a lease subject to a contractual term that obliged them not to use the wire for the transmission of commercial messages. In fact, they did so use the wire and the Privy Council held that they were liable to account to the respondents for the profits made, stating that the defendants held the profits as constructive trustees. As Birks points out, the trust language of the case was purely instrumental, and ought to have been considered without resorting to such result-based reasoning. The respondents would clearly have been entitled to an injunction to prevent the appellants from misusing the wire. Disgorgement damages in the case can be seen as a recognition that there was no way in which damages could be calculated so as to accurately reflect the performance to which the respondents were entitled. This is the kind of breach that needs to be deterred, and so the use of disgorgement damages can be seen as entirely proper. On the other hand, the legal tools available to calculate damages have developed since 1912, and a modern court might see a Wrotham Park award as an appropriate way to calculate the claimant's loss in such a case.

The next case is that of British Motor Trade Association v Gilbert, ${ }^{62}$ where the claimant had sold a car to the defendant, the contract prohibiting

\footnotetext{
${ }^{59}$ See, for example, Tito v Waddell (No. 2) [1977] Ch 106, p 332 (Megarry VC).

${ }^{60}$ Birks, above $\mathrm{n} 9$, at 430 .

${ }^{61}$ [1912] AC 555.

${ }^{62}$ [1951] 2 All ER 641.
} 
resale within two years unless the BMTA were first given the option of repurchasing the car at the original list price. This was in order to defeat the post-war black market in cars. The defendant then sold the car on the black market, for a substantial profit over the list price, and the claimant sought damages. Danckwerts J calculated the damages by reference to the market price that the defendant had obtained notwithstanding the absence of such an open market. Birks regards the case as one where an award of disgorgement damages would have avoided the contortions required to give the same sum on a compensatory basis. This case is yet another where there are clear problems in assessing the compensatory sum, due to the presence of a black market, and one where an injunction could have been obtained if requested early enough. The whole point of the contractual provision was to uphold a larger scheme in order to defeat the black market. A deterrent was needed in order to protect the BMTA's scheme and this deterrent was served by the requirement to disgorge profits. Later purchasers of the car from the BMTA should have known that they had nothing to gain by breaking the contract.

The final case referred to by Birks is one already mentioned, Lake $v$ Bayliss, ${ }^{63}$ where there was an alleged contract for the sale of land, which the vendor then sold to somebody else for an increased price. On the hypothesis that the alleged contract was good, Walton $\mathrm{J}$ decided that the claimant was entitled to the money received from the second purchase by reason of a constructive trust. It is submitted that the same result could have been reached through the contract itself. It was one that was specifically enforceable, reflecting the law's acknowledgement that particular pieces of land are unique, so that the promise could only be fulfilled by the conveyance of the land identified. It is therefore appropriate to deter those who would seek to refrain from performance by allowing a claim for disgorgement damages.

Other cases which need to be considered are cases in which the monetary sum awarded to the claimants was based upon the price that could have been charged by the claimant for the relaxation of the broken covenant. The value of the award has not, in these cases, been calculated by reference to the covenant itself, or the loss to the claimant, but by reference to a percentage of the profit made by the defendant. The clearest case is that of Wrotham Park Estate Co $v$ Parkside Homes, ${ }^{64}$ where the defendant breached a restrictive covenant not to build on land, thereby making a profit. Brightman $\mathrm{J}$ gave the claimants a sum equivalent to $5 \%$ of the defendant's profit.

We immediately run into the question whether these are properly to be seen as disgorgement damages, restitutionary damages or compensatory damages. Edelman regards them as restitutionary damages, seeing the award as reflecting the value of the right which moved between the claimant and the

\footnotetext{
${ }^{63}$ Above $\mathrm{n} 46$.

${ }^{64}$ [1974] 1 WLR 798.
} 


\section{DISGORGEMENT DAMAGES FOR BREACH OF CONTRACT}

defendant. The value of that right was calculated by reference to the "sum of money as might reasonably have been demanded by the plaintiffs from [the defendant] as a quid pro quo for releasing the covenant." ${ }^{65}$ It would, however, be possible to see the sum awarded as a rough-and-ready calculation of the claimant's lost bargaining opportunity, and so the award could be seen as compensatory. This compensatory analysis was preferred by the Court of Appeal in Jaggard $v$ Sawyer, ${ }^{66}$ but was rejected by the Court of Appeal in Surrey County Council v Bredero, ${ }^{67}$ where the Wrotham Park award was seen as based upon the defendant's gain. In Blake Lord Nicholls considered Wrotham Park to be a "solitary beacon" 68 demonstrating that damages are not tied to provable financial loss, and could be measured by reference to the defendant's gain. The idea that damages are "measured" by reference to profit does not, however, mean that they are given because of the fact of profit. It has been said in a more recent case that:

"It is natural to pay regard to any profit made by the wrongdoer (although a wrongdoer surely cannot always rely on avoiding having to make reasonable recompense by showing that despite his wrong he failed, perhaps simply due to his own incompetence, to make any profit)."

This passage suggests that the sum awarded is attempting to be an objective measure of the loss to the claimant, and is not based on the profit to the defendant. So, even if profit had not been made the court would try to award the same sum for the claimant's losses. The latest case to consider Wrotham Park damages also suggests that they are compensatory. ${ }^{70}$

These cases have centred around restrictive covenants, and these normally entitle the claimant to seek an injunction. In fact, an injunction is precisely what the claimants were seeking in Wrotham Park itself; Bingham J held that he could not grant one, however, as it would be an "be an unpardonable waste of much needed houses to direct that they now be pulled down." ${ }^{, 71}$ The availability of injunctions was one factor, above, which led to the conclusion that some breaches of contract need to be deterred. It can be asked, therefore,

\footnotetext{
${ }^{65}$ Ibid, at 815 .

${ }^{66}$ [1995] 1 WLR 269.

${ }^{67}$ [1993] 1 WLR 1361.

${ }^{68}$ Blake, above n 1 , at 283.

${ }^{69}$ Experience Hendrix v PPX Enterprises [2003] EWCA Civ 323, per Mance LJ at para [26].

${ }^{70}$ WWF-World Wide Fund for Nature (formerly World Wildlife Fund) $v$ World Wrestling Federation Entertainment Inc [2007] EWCA Civ 286, though the logic of this case is doubted below.

${ }^{71}$ Above n 64, at 811 .
} 
why Bingham $\mathrm{J}$ did not deter future breaches of restrictive covenants by awarding full disgorgement damages. The answer may be that the presence of injunctions is generally sufficient to protect both the individual claimants and the institution of restrictive covenants. The fact that disgorgement damages were not given should not encourage future defendants from thinking that they can ignore the covenants, as claimants already have a powerful weapon to prevent that from happening.

Another distinguishing factor between these cases and full disgorgement may be the wider view taken of the defendants' conduct; they did breach their contract, but they did not undermine a wider scheme. In the BMTA case above, and Blake, the breaches of contract destroyed the integrity of wider contractual schemes set up by the claimants. Whilst many claimants who benefit from a restrictive covenant would be willing to relax it for a fee, the government would never let a spy betray confidences and then write about his actions for any amount of money.

As we have seen with the cases above, the courts do not always grant specific performance or injunctions, even where damages are insufficient to compensate the claimant. In Co-operative Insurance Society v Argyll Stores, ${ }^{72}$ for example, the trial judge refused to require a supermarket to stay open, even though the defendant had contracted to do so. The supermarket was losing money, so it had been shut by its operator, without finding an assignee for the lease. Although the Court of Appeal thought that the order for specific performance should be awarded, the House of Lords unanimously held that it should not. Key to the reasoning was that such an order would be difficult to supervise, and would be oppressive to the defendants. It can be asked whether disgorgement should have been awarded in such a case. To the extent that the only obstacle to specific performance was practical, it seems that the defendant shouldn't be allowed to ignore its contractual obligations, leaving the claimant without its performance interest. The court could have calculated how long it would have taken to find an assignee and awarded the losses avoided by the supermarket in that period. ${ }^{73}$

\section{(b) Attorney General v Blake}

The Reid-Newfoundland and BMTA cases described are only weak authority for deterrence-based analysis, as none consider themselves to be giving disgorgement damages for breach of contract. The awards were given either on trust principles or as compensation for breach of contract. Attorney

${ }_{72}^{72}$ [1998] AC 1.

${ }^{73}$ In fact, the supermarket did find an assignee prior to the case reaching the House of Lords. 


\section{DISGORGEMENT DAMAGES FOR BREACH OF CONTRACT}

General $v$ Blake ${ }^{74}$ is different, however, in that it was the first time that the question of disgorgement damages for breach of contract had been confronted head-on.

Upon escaping from prison the traitor George Blake fled to Moscow, and he later wrote an autobiography which included material he had obtained as a spy. Such actions amounted to a crime in England, under the Official Secrets Act 1989 , but it was clear that a prosecution on that basis would never be possible. The Blake case arose because the British government had discovered that Blake's publishers, Jonathon Cape, had agreed to pay large sums to him as advances of royalties and the government wished to prevent him from obtaining sums that had not yet been paid to him. Blake had signed a contract upon entering into the Secret Intelligence Services, which obliged him to seek approval before publishing any material relating to the intelligence service. As he had not received such approval he was clearly in breach of his contract. Their Lordships, therefore, had to answer the question as to what damages, if any, could be awarded for such a breach. Crucial to the case was the fact that the Crown was unable to prove any losses. The Crown was, however, awarded an account of profits.

Much of Lord Nicholls' leading speech (with whom Lords Goff, BrowneWilkinson and Steyn concurred) is directed at demonstrating that in other areas of the law compensation is not the only remedy that is available. This leads him to conclude that there is no logical reason why disgorgement damages ought not to be available for some breaches of contract. The award should, however, be given only in "exceptional circumstances" and, whilst deliberately not setting down fixed rules, Lord Nicholls stated that in future cases:

"The court will have regard to all the circumstances, including the subject matter of the contract, the purpose of the contractual provision which has been breached, the circumstances in which the breach occurred, the consequences of the breach and the circumstances in which relief is being sought. A useful general guide, although not exhaustive, is whether the plaintiff had a legitimate interest in preventing the defendant's profit-making activity and, hence, in depriving him of his profit." 75

It is not at all clear what cases he envisages falling within this broad guideline, and it is thus hard to know whether the "legitimate interest" of which he speaks is equivalent to the approach taken in this article. Does it reflect an idea that compensatory damages would leave the claimant without

\footnotetext{
${ }^{74}$ Above $\mathrm{n} 1$.

${ }^{75}$ Ibid, at 285 .
} 
the full equivalent of performance, and that specific performance cannot be granted?

The inadequacy of the standard secondary obligations, a feature key to the analysis above does feature prominently in Lord Nicholls' reasoning:

"Normally the remedies of damages, specific performance and injunction, coupled with the characterisation of some contractual obligations as fiduciary, will provide an adequate response to a breach of contract. It will be only in exceptional cases, where those remedies are inadequate, that any question of accounting for profits will arise." 76

Lord Nicholls then says:

"In the same way as a plaintiff's interest in performance of a contract may render it just and equitable for the court to make an order for specific performance or grant an injunction, so the plaintiff's interest in performance may make it just and equitable that the defendant should retain no benefit from his breach of contract.",77

This appears to agree that the protection of the performance interest, as described above, will sometimes justify disgorgement damages. However, if his Lordship regards such damages as acting in the same way as specific performance, as suggested by this dictum, it parts company with the deterrence approach. It has been argued that disgorgement damages do not protect the performance interest, but work to deter future breaches. In other words, it has been argued that the goal of the court should not relate to the instant case of profit-making activity, but should relate to the prevention of future occurrences of such breaches. It is too late to protect the performance interest in the case before it, but the court can attempt to ensure that the performance is respected in future instances. It is respectfully submitted that this analysis is more appropriate because there is no apparent link between disgorgement damages and the performance interest, and Lord Nicholls does not provide one.

Though their Lordships did not award an account of profits on the deterrent basis, the facts of the case clearly fit the approach. Damages based on the loss of the Crown's performance interest would have been incapable of proper measurement (Blake "caused untold and immeasurable damage to the public interest" ${ }^{\text {"78 }}$ ) and it was far too late to issue an injunction to prevent him

\footnotetext{
${ }^{76}$ Ibid.

${ }^{77}$ Ibid.

${ }^{78}$ Ibid, at 286 (Lord Nicholls).
} 


\section{DISGORGEMENT DAMAGES FOR BREACH OF CONTRACT}

from publishing the book. Disgorgement damages would have done little to improve the Crown's performance interest in the case, but they can be expected to have done much to discourage future breaches of similar contracts. The potential contract-breaker should know she has nothing to gain and will not bother to write a book from which she cannot profit.

\section{(c) Post-Blake}

There have been a number of cases $^{79}$ and one arbitration ${ }^{80}$ in which the courts have been asked to apply the Blake "legitimate interest" test so as to award disgorgement damages for breach of contract. Only in Esso v Niad was the court willing to accede to this request. That case concerned a petrol station that had agreed with Esso to sell Esso's petrol at a price fixed by Esso, and for which the petrol station owners received price support. They breached this agreement, however, by accepting the price support but selling the petrol above the set price. Morritt VC considered the case to come within the guidance given by Lord Nicholls, as the breaches had been deliberate and had undermined the whole scheme that Esso had set up. In addition it was seen as relevant that it would be impossible to prove the extent of the losses sustained by Esso. ${ }^{81}$ So, this case seems to fit neatly into the pattern that ought to give rise to disgorgement damages. Damages were impossible to prove, and specific performance was no longer possible. Esso's whole scheme depended upon individual petrol stations living up to their contractual obligations; it was thus important that they be able to deter future breaches of the type found in this case.

The arbitration tribunal's decision, the Sine Nomine, also fits the approach of this article, as it concerned the breach of contract by the withdrawal from service of a chartered vessel. The contract was a commercial one, and the arbitration tribunal was clear:

"There should not be an award of wrongful profits where both parties are dealing with a marketable commodity - the services of a ship in this case - for which a substitute can be found in the market place." 82

In such situations damages would be an adequate substitute for the promised performance and so deterrence is not required. The tribunal's

\footnotetext{
${ }^{79}$ Esso Petroleum Co Ltd v Niad Ltd [2001] EWHC Ch 458; Experience Hendrix LLC v PPX Enterprises Inc [2003] EWCA Civ 323; WWF-World Wide Fund for Nature (formerly World Wildlife Fund) v World Wrestling Federation Entertainment Inc [2007] EWCA Civ 286.

${ }^{80}$ AB Corporation v CD Company 'The Sine Nomine [2002] 1 Lloyd's Rep 805.

${ }^{81}$ Esso v Niad, above n 79, at para [56].

${ }^{82}$ Sine Nomine, above n 80, at para [10].
} 
decision also gives weight to one of the underlying notions of contractual promises, that the promise does not entitle a party to performance, within English law, where the equivalent of that performance can be provided by a monetary award. It is taken as granted by the tribunal that "[i]nternational commerce on a large scale is red in tooth and claw", ${ }^{83}$ and the tribunal does not appear to see such deliberate breaches as something that need to be deterred.

The Court of Appeal in Experience Hendrix ${ }^{84}$ rejected the claimant's request for full disgorgement damages on the basis that there was no analogy between Blake's Secret Intelligence Services contract and an agreement as to the retail rights for the songs of Jimi Hendrix. Instead the Court of Appeal granted an award of damages based on a reasonable sum that could have been obtained for the relaxation of the contract, on the Wrotham Park line of authority. It appears from the way in which the matter is approached that the court viewed Blake's full disgorgement of damages as on a sliding scale with Wrotham Park damages, based on a proportion of the profits made. The question that tips the balance from one to the other is apparently the question of exceptionality. This idea of a sliding scale must be challenged. Wrotham Park damages are based on a right of the claimant's which has not been respected, and represent payment for that infringement. Full disgorgement, however, rests upon the notion of deterrence, thus depending on a completely different rationale. The use of Wrotham Park damages in Experience Hendrix can, however, be seen as a decision that in the case such damages do represent the full performance interest.

The final case to consider full disgorgement damages involved the use of the initials "WWF" by the World Wrestling Federation. ${ }^{85}$ Litigation dating back to 2001 had established a breach of contract by the Federation, and the claimant owners of the trademark had failed in a previous attempt to seek full disgorgement damages. Returning to the High Court in 2006 the Claimants sought Wrotham Park damages, and their claim was allowed to proceed. The Defendants appealed on the basis that any claim for Wrotham Park damages should have been brought at the same time as the earlier claim for full disgorgement damages.

Chadwick LJ gave the judgment of the Court of Appeal, in which he asked whether the two types of damages have the same juridical basis, the Defendants saying that they are both gain-based. After analysing the Wrotham Park line of authority his Lordship held that they should be treated as

\footnotetext{
${ }^{83}$ Ibid, at para [9].

${ }^{84}$ Experience Hendrix LLC v PPX Enterprises Inc [2003] EWCA Civ 323.

${ }^{85}$ WWF-World Wide Fund for Nature (formerly World Wildlife Fund) $v$ World Wrestling Federation Entertainment Inc [2007] EWCA Civ 286.
} 


\section{DISGORGEMENT DAMAGES FOR BREACH OF CONTRACT}

compensatory. ${ }^{86} \mathrm{He}$ did, however, find in favour of the Defendants, holding that the Blake award of an account of profits was also compensatory. He justified this on the basis that both awards become available where loss cannot be identified, so the courts make a "flexible response to the need to compensate the Claimant for the wrong which has been done to him." $" 87$

In many ways Chadwick LJ's analysis matches that of Lord Scott's argument, considered above. ${ }^{88}$ Whereas Lord Scott accepts that his analysis contradicts Lord Nicholls, ${ }^{89}$ however, Chadwick LJ suggests that he is following the Blake case. Treating the Blake case as the application of compensatory principles does seem to fly in the face of much of Lord Nicholls' language. His Lordship's speech focuses on George Blake's gain, not the Security Services' loss, and there is no attempt to marry the loss to the award. Lord Scott, in opposing damages that are not compensatory, calls upon us to "call a spade a spade." 90 To call Blake "compensatory" fails to do so.

\section{CONCLUSION}

It has been argued that the disgorgement damages can be seen as having a principled basis. This basis depends on the idea that the generally applicable secondary remedies, of damages backed-up by specific performance, are geared towards the protection of the promisee's performance interest. In some situations, however, those awards fail to live up to the performance interest, and in such cases deterrence is required. Disgorgement damages are the way in which this deterrence is effected.

It is far from clear that the solution laid out in this essay is the one operating on the minds of the judiciary when they award disgorgement damages. It is submitted, however, that the analysis used herein is in line with a proper understanding of the performance interest, which is engaged whenever a contract is formed with English law. Admittedly the law can change direction on such matters, but the Israeli solution which creates a nearabsolute obligation to perform has not been accepted in English law. At present a breach of contract generates the obligation to pay damages as an alternative to performance. Only where this monetary substitute fails to be an adequate substitute for performance, and only where performance itself is impossible to achieve, are disgorgement damages supportable.

\footnotetext{
${ }^{86}$ Ibid, at para [57].

${ }^{87}$ Ibid, at para [59].

${ }^{88}$ Above $\mathrm{n} 3$.

${ }^{89}$ Ibid, at 468: "Lord Nicholls, while approving [the Wrotham Park] cases, regarded them as an exception to the general rule that damages should be compensatory. I respectfully disagree."

${ }^{90}$ Ibid, at 469.
} 